\title{
A CIDADE REINVENTADA NAS CHARGES DE YANTOK
}

\author{
Marilda Lopes Pinheiro Queluz ${ }^{1}$
}

A proposta deste texto é refletir sobre o humor gráfico de Max Yantok (1881$1964)^{2}$, especialmente as charges feitas sobre o Rio de Janeiro, entre 1915 a 1920, consultadas em revistas e periódicos do acervo da Casa da Memória de Curitiba. Max Yantok ficou famoso pela criação dos quadrinhos de aventuras de Pipoca e Kaximbown, publicados na revista Tico-Tico, voltada para o público infantil. Entretanto, o enfoque desta pesquisa está no modo como este desenhista procurou captar as cenas do dia a dia carioca, produzindo crônicas visuais, usando a linguagem das narrativas sequenciais para traduzir a dinâmica da vida na capital, os comportamentos e hábitos urbanos.

A temática da cidade e os efeitos de seu crescimento e modernização ocuparam muitas páginas das revistas ilustradas do período. Mas foi pelas mãos dos caricaturistas que esse universo de representação ganhou ares de perplexidade, estranhamento e decepção.

\begin{abstract}
Espremida, de um lado, pelos rarefeitos circuitos da cultura do livro, e, de outro, pelos circuitos mal definidos e instáveis do periodismo semanal e dos espetáculos ligeiros do teatro de revista, resta saber, por que, no período crítico da história brasileira e mundial que foram as três primeiras décadas do século (XX), esta representação humorística ocupou um espaço que, se não foi enorme, revelou-se importante e de notável regularidade. (Saliba, 2002: 36)
\end{abstract}

Essas representações do cotidiano devem ser estudadas na historicidade dos regimes visuais, considerando: as negociações de sentidos e significados entre os desenhistas e os leitores das imagens veiculadas pela imprensa; os contextos de leitura; as contaminações entre caricaturas, fotografias, ilustrações, textos e editorial das revistas; os dispositivos técnicos para a produção das imagens.

\footnotetext{
1 Universidade Tecnológica Federal do Paraná - Brasil.

2 Max Cesarino Yantok nasceu provavelmente em 1881, no Rio Grande do Sul, filho de um imigrante italiano e de uma índia brasileira. Quando pequeno viajou para a Itália com o pai, onde começou a desenhar, estudou violino e pintura. Versátil e com múltiplos talentos, Yantok destacou-se em diversas áreas. Diplomou-se como engenheiro agrimensor e contador (Fonseca, 1999: 228) Fez caricaturas para o jornal italiano L'Asino e colaborou com os periódicos franceses Péle-Méle e L'Assiette au Berre. Em 1908 foi para o Rio de Janeiro e, em 1911, iniciou sua longa participação na revista Tico-Tico, criando as aventuras de Pipoca e Kaximbown, que se passavam em Fantasiópolis, na Pandegolândia, na G'astronomia, no Polo Norte e no fundo do mar (Lima, 1963).
} 
Compreendida como resultante de uma relação entre sujeitos, a imagem visual engendra uma capacidade narrativa que se processa numa dada temporalidade. Estabelece, assim, um diálogo de sentidos com outras referências culturais de caráter verbal e não-verbal. As imagens nos contam histórias (fatos/acontecimentos), atualizam memórias, inventam vivências, imaginam a História. (Mauad, 2005: 135)

Roger Chartier (1990) lembra que para compreender uma dada realidade social é necessário interrogar o modo como ela se constituiu como foi apresentada, representada, interpretada, apropriada. As percepções do social não são discursos neutros, pois apontam estratégias, práticas e relações de poder, legitimando ou justificando escolhas e comportamentos.

É importante ressaltar que o conceito de representação proposto aqui vem sendo construído a partir de discussões caras aos estudos culturais e à história das artes gráficas. Para Stuart Hall (1997), as representações são interpretações de algum referente, materializadas através da linguagem; um sistema sociocultural de codificação das ideias sobre o mundo, capaz de evocar e compartilhar significados que têm efeitos reais, regulando práticas sociais e assinalando diferenças.

Já para Chartier, as representações estão

sempre colocadas num campo de concorrências e de competições cujos desafios se enunciam em termos de poder e de dominação. As lutas de representações tem tanta importância como as lutas econômicas para compreender os mecanismos pelos quais um grupo impõe, ou tenta impor, a sua concepção do mundo social, os valores que são os seus, e o seu domínio.(Chartier, 1990: 17)

$\mathrm{Na}$ constituição de novas visualidades do início do século $\mathrm{XX}$, o humor gráfico alinhou-se ao desenvolvimento técnico da imprensa e ao crescimento da indústria cultural, representando, entre a crítica e o conformismo, a ideia de moderno e de progresso. Para entender as imbricadas relações entre os contextos de produção, circulação, consumo e apropriação destas imagens, é fundamental levar em conta que

A produção das representações é uma dimensão da práxis social tanto quanto as ações efetivamente realizadas pelos agentes sociais. Pensar e representar são momentos da práxis tanto quanto agir, este e aqueles exprimindo, dramatizando e ocultando uns aos outros no movimento pelo qual uma sociedade se efetua como sociedade determinada"(Chauí \& Franco, 1978: 9)

Com relação à linguagem da caricatura e do humor gráfico, observa-se um tipo de representação bem específico, que busca inverter a lógica hegemônica, mostrar o seu avesso, multiplicar os olhares sobre um dado acontecimento ou uma dada situação, 
desdobrando as possibilidades interpretativas:

\begin{abstract}
As representações humorísticas nas suas inúmeras formas e procedimentos, forjamse nos fluxos e refluxos da vida, no tecido histórico e social - já que cada sociedade cria e inventa seus próprios espassos de repressão e transgressão. Além de colocar-se como uma invenção histórica e social, a atitude humorística é vista como parte indistinta dos processos cognitivos, pois ela partilha, como jogo, a arte e o inconsciente, o espaço do indizível, do não dito e, até, do impensado [...] podemos caracterizar a representação humorística, portanto, como aquele esforço inaudito de desmascarar o real, de captar o indizível, de surpreender o engano ilusório dos gestos estáveis e de recolher, enfim, as rebarbas das temporalidades que a história, no seu constructo racional, foi deixando para trás. (Saliba, 2002: 28-29)
\end{abstract}

As primeiras décadas do período republicano no Brasil foram marcadas por mudanças conservadoras: modificou-se a paisagem urbana através de reformas arquitetônicas, ampliação de ruas e criação de avenidas, campanhas de higienização e sanitarismo, esquadrinhamento da população, modernização dos meios de transporte e de comunicação, aprimoramento dos processos gráficos e fotográficos dos periódicos e das revistas. Construía-se um ideal de civilização inspirado nos modelos das cidades europeias, importando e adaptando a moda parisiense e os conceitos das artes de vanguarda. Os intelectuais que trabalhavam nas revistas de humor usaram a ironia e a crítica ao cotidiano para questionar o funcionamento da República e as promessas de progresso e modernidade. Tentava-se, pelo registro cômico, expressar os sentimentos simultâneos de admiração e o temor pela tecnologia, surgidos na interação das pessoas com os novos artefatos científicos e tecnológicos como o automóvel, os bondes elétricos, o telefone, o calçamento, os cinematógrafos, os fonógrafos e gramofones, entre outros. "O cenário que então se abriu era propício a todo tipo de utopia e projeção. A República surgiu alardeando promessas de igualdade e cidadania - uma modernidade que se impunha menos como opção e mais como etapa obrigatória e incontornável.” (Schwarcz, 2012: 19).

$\mathrm{Na}$ Belle Epoque brasileira, paulistas (produtores de café) e mineiros (produtores de leite) se revezavam na presidência da República, originando a chamada "política café com leite". Conjugava-se modernização e tradição, justapondo modernas soluções de engenharia com práticas políticas e trabalhistas ainda do tempo do regime escravocrata. Urbanidade, progresso e industrialização tornam-se termos fundamentais para justificar as políticas públicas e as opções econômicas. A cidade e o espaço urbano impõem-se como "novo lócus das representações" (Schwarcz, 2012: 22).

As grandes metrópoles apresentavam-se como vitrinas de civilidade, anunciando 
as muitas oportunidades de trabalho e de mercado, embora houvesse a exclusão de muitos setores sociais em nome da modernidade e da racionalidade, especialmente da população negra e pobre. Vigoravam modelos deterministas de interpretação social, teorias que defendiam hierarquias entre as raças, usando a ciência e a biologia para explicar os diferentes acessos à cidadania e a desigualdade entre brancos e negros, escamoteando o passado escravocrata.

Afinal, esse foi um contexto em que as práticas coletivas de higienização e de aplicação do determinismo racial levaram a políticas de exclusivismo e de isolamento social, largamente denunciada pelos testemunhos da época. Finda a escravidão, novas modalidades de hierarquia se estabeleceram, sendo a raça e a biologia bússolas a orientar a "nova civilização". (Schwarcz, 2012: 25)

As exposições universais incentivaram o sonho com um progresso constante e linear, e acirraram a imaginação para um futuro em que a ciência e a técnica reduziriam as incertezas, alcançando um total domínio sobre a natureza e a humanidade. Sem conseguir resolver as mazelas da herança escravocrata e de um sistema patriarcal e oligárquico, o regime republicano apostou nos ideais burgueses de civilização e modernidade.

\begin{abstract}
Uma verdadeira batalha simbólica foi travada, quando nomes, símbolos, hinos, bandeira, heróis nacionais foram substituídos com o intuito de impor novas versões mais coadunadas com os tempos modernos. Símbolo maior dessa era, Santos Dumont elevou aos ares as expectativas brasileiras de alcançar as alturas das nações modernas. Ícone dos novos tempos foi também a "nova avenida central" - atual avenida Rio Branco na cidade do Rio de Janeiro -, exemplo maior do projeto urbanístico que transformou a capital federal em verdadeiro cartão postal, com fachadas art nouveau, feitas de mármore e cristal, modernos lampiões a luz elétrica, lojas de produtos importados e transeuntes à francesa. Marco paralelo e complementar a toda essa cantilena de novidades foi a expulsão da população pobre que habitava os casarões da região central e a destruição dos famosos "cabeças de porco". Era a ditadura do "bota-abaixo", que demolia casas, sobretudo as antigas e pobres, disseminando cortiços e hotéis baratos - os "zunga" - onde famílias inteiras deitavam-se no chão ou mudavam-se para as chamadas "periferias" das novas urbes. Isso sem esquecer a repressão às festas populares que se submetiam igualmente a esse processo civilizatório": saía o entrudo mestiço, entrava o limpo Carnaval de Veneza.( Schwarcz, 2012: 44-45)
\end{abstract}

Nesse contexto de entusiasmo com a tecnologia e as novas invenções, de "embelezamento" e "regeneração" das cidades, ao lado de uma política de imigração massiva, cresciam as dúvidas e os questionamentos sobre os caminhos do desenvolvimento, com ideias anarquistas e socialistas, além de aspirações utópicas de um mundo melhor. A Primeira Guerra Mundial (1914-1918) e a Revolução Russa 
(1917) tiveram um grande impacto sobre o modo de encarar a política e o destino das nações. No Brasil, a guerra provocou a substituição de importações, estimulando a produção nacional e o crescimento industrial das cidades.

Vale lembrar que as charges selecionadas para este artigo foram produzidas na época do conflito mundial e os dois anos seguintes, sendo possível perceber a preocupação com os efeitos dos eventos internacionais em nosso país, e o pessimismo quanto ao futuro. Os desenhos de Yantok que tiveram como alvo a cidade, podem ser inseridos naquilo que Saliba (2002: 66) chama de "humorismos da desilusão republicana".

O tema da desilusão republicana é sempre colocado sob a ótica dos interesses individuais das elites brasileiras ou, quando muito, na perspectiva de uma visão doméstica ou mesmo familiar da coisa pública. A mistura, a confusão e a passagem rápida da vida pública para o microcosmo da casa já delineavam o formato do procedimento cômico brasileiro. (Saliba, 2002: 71)

Um exemplo bastante contundente dessa desilusão é a visão do Rio de Janeiro de 1915, como Mendigópolis (figura 1). Na legenda "Um aspecto pitoresco do Rio atual, consequência do nefasto quatriênio 'Corta-jaca"' já têm algumas dicas. A escolha do termo pitoresco remete à tradição da pintura de paisagem pelo olhar dos artistas viajantes e do consumo das vistas veiculadas pelos cartões-postais, tão em voga no início do século XX. O "nefasto quatriênio" parece ser a avaliação do caricaturista à gestão de Hermes da Fonseca (1910-1914) ${ }^{3}$. Corta-jaca era um dos apelidos dados ao presidente e/ou à sua administração, especialmente depois que a primeira-dama, Nair de Teffé ${ }^{4}$, em um sarau no palácio do Catete, tocou ao violão o tango Corta-jaca, de Chiquinha Gonzaga ${ }^{5}$. O evento causou o maior frisson na imprensa e na sociedade, recebendo críticas indignadas de Rui Barbosa, com forte preconceito à música popular. (Lustosa, 1989: 64).

3 Marechal Hermes da Fonseca teve um governo bastante tumultuado, e sua política econômica "demonstrou-se um desastre", deixando o país "ainda mais hipotecado aos bancos estrangeiros." Sofreu grande influência do senador Pinheiro Machado. (Lustosa, 1989: 59)

4 Nair de Teffé (1886-1981) é considerada a primeira caricaturista brasileira e assinava seus desenhos com o pseudônimo de Rian. Seus desenhos foram publicados na revista Fon-Fon, O Cinematógrafo, Careta, O Malho e na Revista da Semana. Em 1913 casou com o Marechal Hermes da Fonseca, então Presidente da República (Fonseca, 1999: 231-232)

5 "A compositora e maestrina carioca Chiquinha Gonzaga (1847-1935) destaca-se na história da cultura brasileira e da luta pelas liberdades no país pelo seu pioneirismo. A coragem com que enfrentou a opressora sociedade patriarcal e criou uma profissão inédita para a mulher, causou escândalo em seu tempo. Atuando no rico ambiente musical do Rio de Janeiro do Segundo Reinado, no qual imperavam polcas, tangos e valsas, Chiquinha Gonzaga não hesitou em incorporar ao seu piano toda a diversidade que encontrou, sem preconceitos.” (Diniz, 2011) 


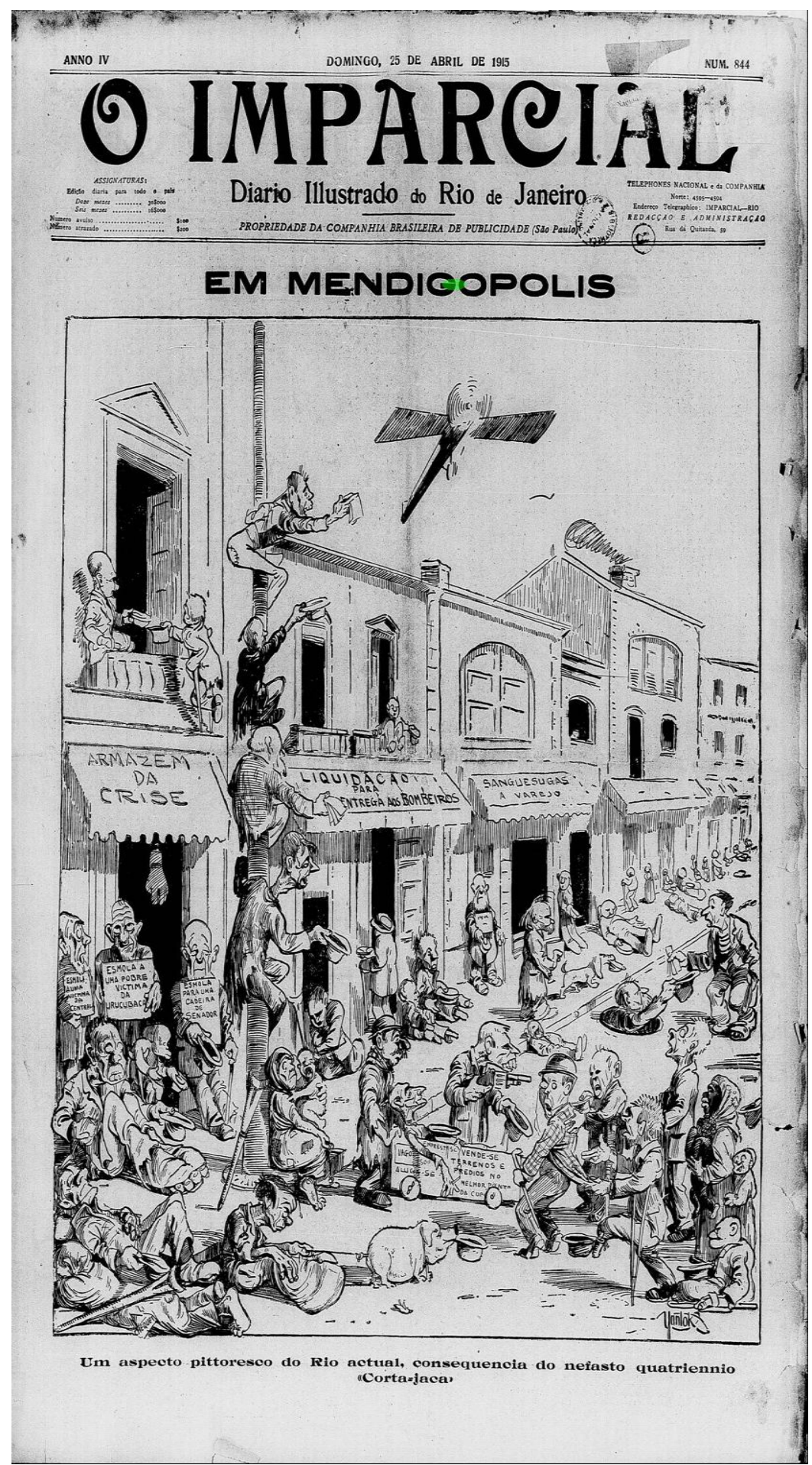

Figura 1 - "Em Mendigópolis" de Yantok

Fonte: O Imparcial, 25/04/1915, n.844. Acervo digital da Biblioteca Nacional

Nesta primeira página do jornal, o Rio é transformado "num monstruoso pátio dos milagres, com mendigos de toda espécie pululando em todos os recantos" (Lima, 1963: 1259). Mostra-se uma população doente, empobrecida, com roupas rasgadas e remendadas, muitos com o auxílio de muletas, quase todos com as mãos e/ou os chapéus estendidos, a espera de uma esmola. Na rua e na calçada, a grande maioria são 
homens (apenas duas mulheres aparecem no primeiro plano) e brancos (somente uma das mulheres é negra). Lê-se nas placas críticas à exploração do comércio, à especulação imobiliária, à corrupção política. Interessante destacar a placa "esmola a uma pobre vítima da urucubaca", pois urucubaca era uma palavra associada ao azar, às influências negativas do marechal-presidente. Segundo Herman Lima (1963: 1257), Yantok, em parceria com Humberto de Campos, redator de O Imparcial, teria inventado a palavra urucubaca, "destinada a estrondosa divulgação no Brasil inteiro, como sinônimo da jettatura (mau olhado, azar, má sorte) atribuída ao Marechal Hermes”.

Duas cenas que chamam a atenção são: os quatro homens escalando o poste à esquerda, parecendo acenar para o avião, em busca de ajuda; e o único senhor bem vestido, sendo assaltado, no canto inferior esquerdo, completando o quadro de violência e desolação.

Algo importante a se observar nas páginas de Yantok é o modo como compõe a sequência das cenas, usando a diagramação como elemento dinâmico e a linguagem dos quadrinhos com forma de evocar o tumulto da cidade, o ritmo das andanças pelas ruas, o bombardeio de imagens e palavras.

Mesmo nas composições em que a divisão dos quadrinhos é bem definida e a narrativa é sequencial, o movimento dos corpos, a variedade de linhas de ação, a gestualidade exagerada e a forte expressividade dos personagens carregam na dinâmica da página, reiterando o ritmo acelerado e complicado dos dias na capital carioca. A figura 2 propõe a reflexão sobre a cidade a partir do olhar de quem chega, do forasteiro que tenta entender e se adaptar aos costumes, aos tempos "modernos" e citadinos. São muitas as aventuras que o esperam ao longo do dia: o entusiasmo da chegada começa a diminuir com o hotel associado a uma lata de sardinhas, o ambiente empoeirado e pouco aconchegante, o atropelamento, a agilidade e o esforço corporal para se agarrar ao bonde em movimento, o café fechado, a falta de garçons no restaurante, a mordida do cão, o escorregão em uma casca de banana; vendo-se impedido pelo guarda de descansar no banco de praça (já que isso era sinônimo de vadiagem), é vítima do desabamento de um prédio, cai em um buraco, é confundido com ladrões de canos, decepciona-se com o tamanho microscópico do pão (comum no tempo da Primeira Guerra Mundial), com o leite aguado, retornando à cama quebrada do hotel. O desfecho com ratos fazendo serenata ao luar parece indicar que só eles aproveitam a cidade. 


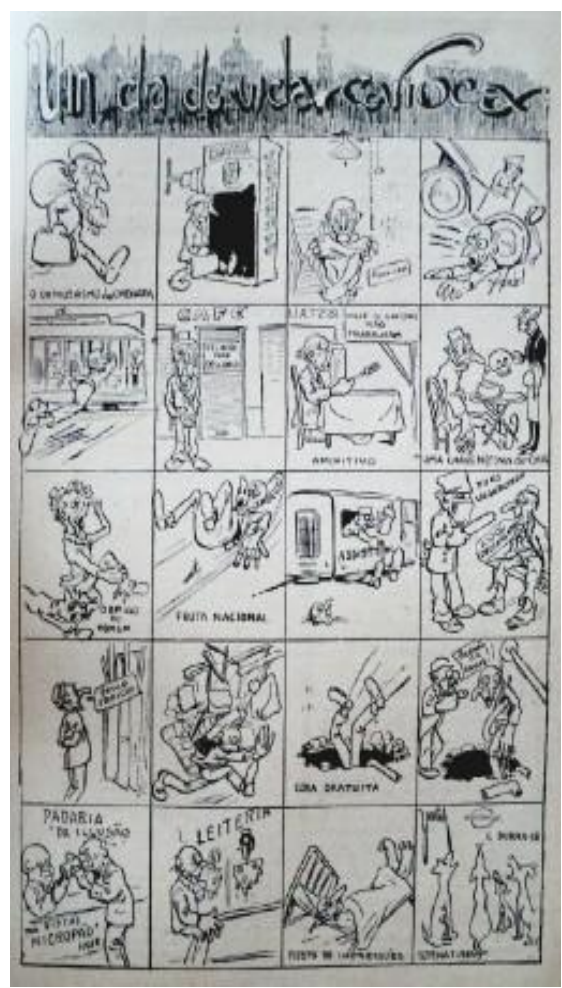

Figura 2 - "Um dia de vida carioca" de Max Yantok

Fonte: Fon-Fon, ano XII, n.12, 23 de março de 1918 - Acervo Casa da Memória de Curitiba

Na mesma perspectiva, mas com uma ênfase ainda maior na decepção com a cidade, na figura 3 vemos o personagem que "chegou... viu...fugiu". Os quadrinhos estão dispostos como fotos/figurinhas jogadas, sobrepostas, desmontando a linearidade da página. 


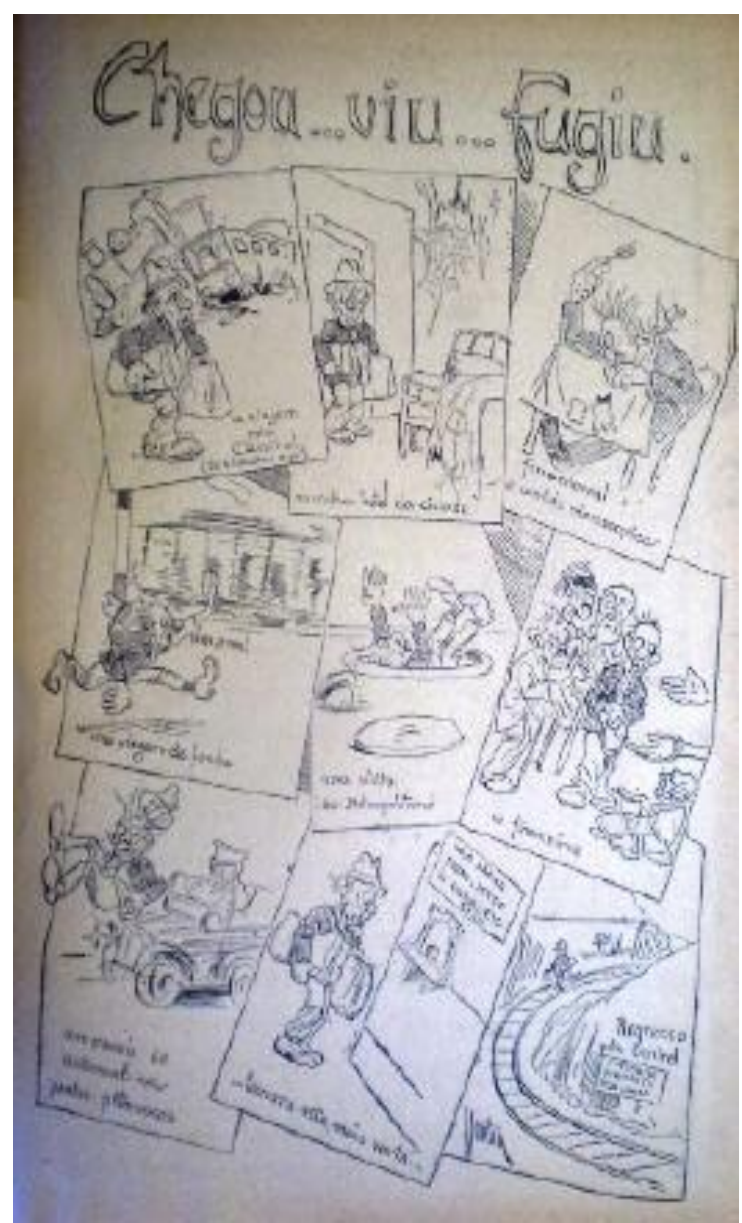

Figura 3 - "Chegou... viu... fugiu." de Max Yantok

Fonte: Fon-Fon, ano XII, n.13, 29 de março de 1919 - Acervo Casa da Memória de Curitiba

O dinamismo das cenas é reforçado pelo excesso de diagonais dos requadros que se entrecruzam. A viagem de trem, ônibus, e os "20 km a pé", a imagem do quarto do "melhor hotel da cidade" com teia de aranha, a toalha de mesa com remendos e "comida microscópica" apontam para as surpresas vividas a cada instante. A dificuldade em pegar o bonde é marcada pelos traços futuristas, pelas silhuetas fora de foco e as linhas de ação, indicando o movimento, a passagem quase fantasmagórica, em contraste com a concretude do corpo estirado do personagem, em um longo salto, em que o pé sai do limite do quadrinho. Com a legenda "uma visita ao Metropolitano", vemos o personagem entalado em um bueiro. Em "os financeiros", vemos o cidadão sendo abordado por muitos pedintes. Na cena de atropelamento, o personagem é quase jogado para fora do quadrinho, enquanto lemos que se trata de "um passeio de automóvel pelos pontos pitorescos". Ao descobrir que não há trens funcionando, o personagem desabafa: “... tomara não mais vortá...”, denunciando o sotaque genérico de quem é do interior. No último quadrinho vemos o forasteiro indo embora a pé, ainda que a placa proíba o trânsito pela linha do trem. Apenas no final descobrimos que o narrador é o próprio 
viajante e as imagens parecem ser lembranças, o registro de sua breve estadia.

Nestes dois exemplos, apagam-se os sinais de modernidade e progresso, questionando as vantagens de se viver em uma cidade grande e civilizada. A viagem é marcada não pelos pontos turísticos, positivos, mas pelos fracassos e desapontamentos, pelas formas de exclusão e marginalização. Os problemas para se locomover evidenciam, além da precariedade do transporte público e dos serviços de manutenção das calçadas, dos edifícios, as armadilhas cotidianas nas quais os indivíduos se sentem perdidos e deslocados.

A estratégia do estranhamento, do distanciamento para se observar melhor os hábitos, os comportamentos, o funcionamento da cidade, foi bastante utilizado por Yantok. É outra maneira de denunciar o descompasso entre as novidades da modernização, a velocidade das mudanças e a realidade das pessoas. Em quase todas as charges de Yantok, os cidadãos aparecem/agem como se estivessem fora deste processo de construção do futuro, como se estivessem sempre à margem dos benefícios da ciência e da tecnologia, como outsiders da história.

Yantok imaginou a cidade e a partir dos hábitos e dificuldades de seus usuários: mendigos, pobres, ladrões, bêbados, estafermos (gíria para pessoas que não faziam nada, eram um estorvo, sem préstimo), namorados, gatos e cachorros. Em "Os projetos de Fon-fon" (figura 4) imaginam-se soluções e máquinas bizarras para problemas corriqueiros, visando facilitar a vida das pessoas. São intervenções/invenções nas ruas que parodiam os projetos urbanísticos e as melhorias municipais. $\mathrm{O}$ bueiro é associado ao lugar para onde vão as economias públicas, a luz elétrica ganha outros usos para os ladrões, o lixo pode ser removido com o "silosmóvel", os desníveis e buracos das calçadas e ruas podem ser evitados com o "levantador para quedas", o "autocurvoscópio" pode auxiliar o trânsito nas curvas, etc. Um mecanismo que destoa dos demais aparatos urbanos é o "avisador de revoluções", com um "receptor de boatos" e as plaquinhas - "monarquia", "república" e "anarquia" - girando em uma ordem que parece sugerir o caminho seguido pelo país, na visão do desenhista. 


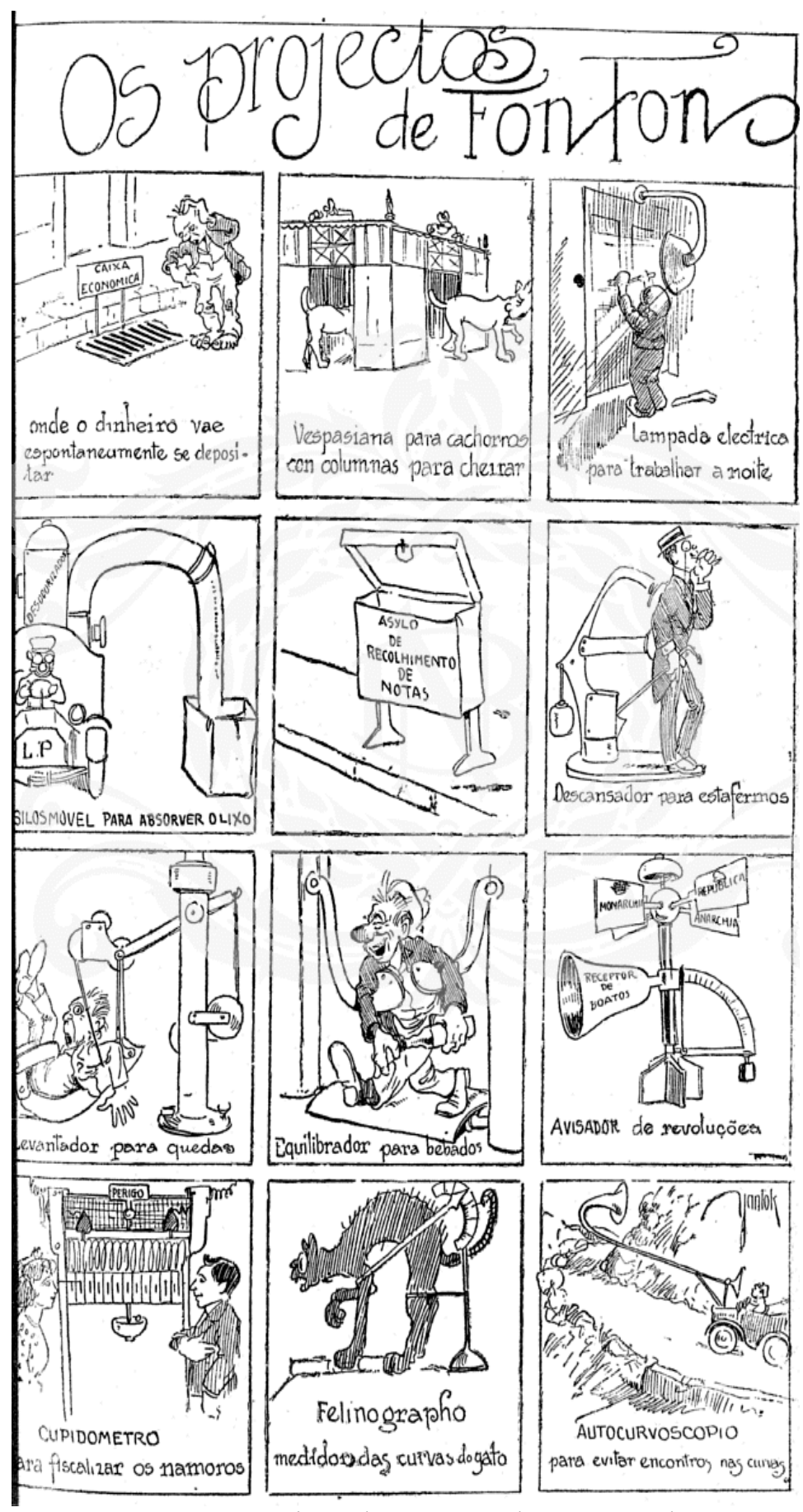

Figura 4- "Projetos de Fon-Fon" de Max Yantok

Fonte: Fon-Fon, ano XIII, n.10, 8 de março de 1919 - Acervo da Casa da Memória de Curitiba

Ao comparar o ano de 1914 com o ano de 1919 (figura 5), o desenhista destaca os efeitos da guerra na economia, com as perdas de títulos e ações, o aumento dos preços dos alimentos e do vestuário, o oportunismo do comércio; aponta as mudanças nas aparências das pessoas, dos ambientes e das posturas corporais. Mas é no vazio da rua, na transformação das fachadas (figura 6) que a pauperização se torna mais expressiva, que a sensação de abandono e descaso ganha detalhamento e texturas. Ainda que o 
objetivo da coluna à direita fosse traçar as marcas do pós-guerra, os quadrinhos da esquerda acabam por desvelar a cidade ambicionada pela burguesia e idealizada por caricaturistas como Yantok.

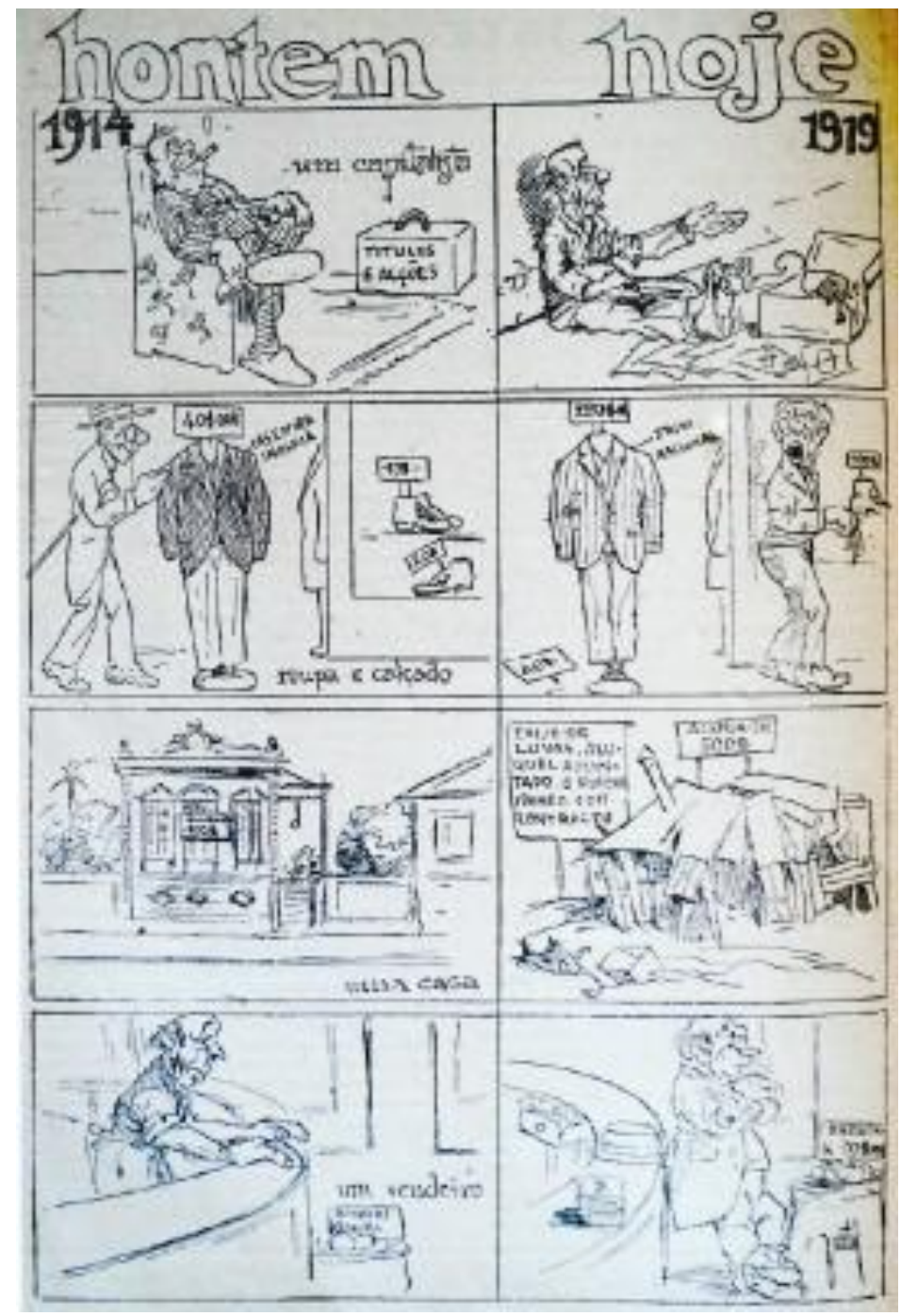

Figura 5 - "Ontem e Hoje" de Max Yantok

Fonte: Fon-Fon, ano XIV, n.04, 24 de janeiro de 1920 - Acervo da Casa da Memória de Curitiba

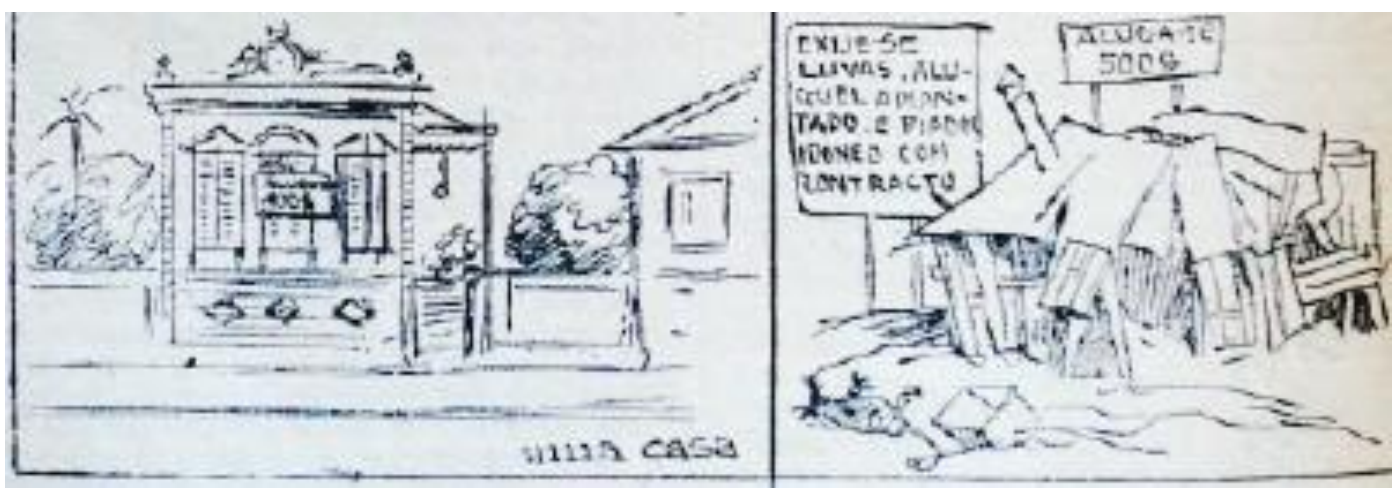

Figura 6 - "Ontem e Hoje"(detalhe) de Max Yantok

Fonte: Fon-Fon, ano XIV, n.04, 24 de janeiro de 1920 - Acervo da Casa da Memória de Curitiba 
Muitas utopias foram criadas com base na crença do progresso, unindo racionalismo, tecnologia e modernidade. De acordo com Gregory Claeys (2013: 113), "Com a urbanização extrema, a imagem da cidade tende para a distopia". Na cidade representada pelos traços de Yantok, vêem-se muitos elementos distópicos, sente-se uma grande dose de nostalgia, clamando por um passado supostamente melhor, mas jamais alcançado. É uma perspectiva conservadora que compara o passado e o presente, apegando-se a uma tradição inventada pelas elites burguesas, duvidando de um futuro possível, viável.

A resistência às mudanças e a visão melancólica acabam por questionar os valores sociais do momento, provocando deslocamentos reflexivos. Vita Fortunati afirma que há uma proximidade entre utopia, melancolia e sátira, pois exprimem a desarmonia com o tempo em que se vive. Para a autora, assim como o escritor utópico, o escritor satírico é sempre impregnado pela melancolia e busca certo isolamento da realidade de seu tempo. Ambos deslocam-se para assumir uma atitude crítica e desconstrutiva em relação à sociedade contemporânea, numa corrosiva recusa ao mundo como se apresenta. $\mathrm{O}$ escritor satírico quer dissecar o mundo para expelir o mal, faz uma anatomia do real para revelar os seus defeitos, mas não cria um projeto como o escritor utópico. (Fortunati, 2005: 142).

Mas, nas charges de Yantok, há projetos. Ainda que predomine um determinismo tecnológico em que a vida das pessoas é definida pelos artefatos, consequência inevitável da evolução técnica há tentativas de reinventar a realidade. De modo irreverente, propõem-se interferências no cotidiano. A sugestão de dispositivos, máquinas e artifícios antifuncionais, impossíveis, inverte a lógica cientificista, leva ao riso que desperta o sonho de cidadania, e permite vislumbrar apropriações alternativas da cidade, alimentando um novo imaginário social.

\section{Referências}

CHARTIER, Roger. A história cultural. Entre práticas e representações. Tradução Maria Manuela Galhardo. Lisboa: Difel; Rio de Janeiro: Bertrand Brasil, 1990

CHAUÍ, Marilena \& FRANCO, Maria Sylvia Carvalho. Ideologia e Mobilização Popular (Rio de Janeiro: Paz e Terra:CEDEC, 1978).

CLAEYS, Gregory. Utopia. A história de uma ideia. São Paulo: Edições SESC SP, 2013.

COSTA, Ângela Marques da \& SCHWARCZ, Lilia Moritz. 1890-1914 No tempo das certezas. São Paulo: Companhia das Letras, 2002. 
DINIZ, Edinha. Biografia. In Acervo Digital Chiquinha Gonzaga. Disponível em <http://www.chiquinhagonzaga.com/acervo/?page_id=1781>, acesso em 27 mar. 2014

FONSECA, Joaquim da. Caricatura: a imagem gráfica do humor. Porto Alegre: Artes \& Ofícios, 1999

FORTUNATI, Vita. Utopia and Melancholy: an intriguing and secret relationship in MORUS. Utopia e Renascimento. Dossiê: Utopia como gênero literário. Campinas, SP, Unicamp, n.2, 2005, pp.137-151.

HALL, Stuart. A centralidade da cultura: notas sobre as revoluções culturais do nosso tempo. Educação \& Realidade, Porto Alegre, v. 22, no2, p. 15-46, jul./dez. 1997.

LIMA, Herman. História da Caricatura no Brasil. Rio de Janeiro: J. Olympio, 1963. v.3

LUSTOSA, Isabel. Histórias de Presidentes. A República do Catete. Petrópolis, RJ: Vozes; Rio de Janeiro: Fundação Casa de Rui Barbosa, 1989.

MAUAD, Ana Maria. "Na mira do olhar: um exercício de análise da fotografia nas revistas ilustradas cariocas, na primeira metade do século XX".In: Anais do Museu Paulista. v. 13. n.1. jan.- jun. 2005, p.133-174.

SALIBA, Elias Thomé. "Cultura / As apostas na República". In: SCHWARCZ, Lilia Moritz (org.) A abertura para o mundo: 1889-1930. História do Brasil Nação 1808-2010, volume 3. Rio de Janeiro: Objetiva, 2012, p.239-294.

SALIBA, Elias Thomé. Raízes do riso. A representação humorística na história brasileira: da Belle Époque aos primeiros tempos do rádio. São Paulo: Companhia das Letras, 2002.

SCHWARCZ, Lilia Moritz. "Introdução - As marcas do período; População e sociedade." In: SCHWARCZ, Lilia Moritz (org.) A abertura para o mundo: 1889-1930. História do Brasil Nação 1808-2010, volume 3. Rio de Janeiro: Objetiva, 2012, p.19-83. 